\title{
Tabot Culture: Local Wisdom of the Bengkulu Community and Effort to Preserve it
}

\author{
Widanita; Risma Margaretha Sinaga; Muhammad Mona Adha \\ Master of Social Science Education, Faculty of Teacher Training and Education, University of Lampung, Indonesia
}

http://dx.doi.org/10.18415/ijmmu.v8i9.2958

\begin{abstract}
This study aims to analyze and describe the values of local wisdom in the Tabot culture in the community, as well as efforts to preserve the values contained in the Tabot culture. This study uses a qualitative approach. Data collection techniques using interviews, observation, and documentation. The data analysis technique uses an interactive pattern of Miles and Huberman data. The results of this study indicate that the form of local wisdom of the Tabot culture consists of local wisdom in the form of musical instruments used in the Tabot ceremony, traditional clothing, and the local language used as well as food and drinks. While local wisdom is intangible in the form of values contained in the Tabot ceremony, including the prayer of salvation which contains the meaning to always remember Allah SWT, asking for the safety of the hereafter, and safety during the implementation of the Tabot ritual. Efforts to preserve Tabot culture are influenced by several inhibiting berdoas, including the lack of support from the local government, negative perceptions of non-Tabot communities towards Tabot culture, conflicts among Tabot family members, and the values contained in each Tabot ritual are less socialized. As for the supporting berdoas in general, there is sosial support from several parties, namely support from the descendants of the Tabot family, support from the community, and support from art studios in Bengkulu.
\end{abstract}

Keywords: Local Wisdom; Tabot Culture; Cultural Preservation

\section{Introduction}

Indonesia is a country with diverse ethnic groups, languages, ethnicities, religions and customs, each of which is unique. Cultural diversity is what attracts other nations to know, or even not a few of them who later learn about it. According to Koentjaraningrat, (in Gumay, 2011) culture is a product of a society whose function is as a tool to express various kinds of meaning, both for the supporting community and outsiders who have the interests of the community. The scope of society creates different cultures, but the main content of culture in the world is included in the elements of culture, namely language, knowledge system, social organization, livelihood system, religious system, and art. In the context of understanding a pluralistic society, in addition to the culture of ethnic groups, Indonesian society also consists of various regional cultures which are a meeting of various cultures of ethnic groups in the area. Therefore, it is undeniable that each tribe has a different culture.

Boas (1938) expressed his opinion that culture is the sum total of mental reactions, physical and behavioral character activities of individuals that change a social group collectively and individually in relation to the natural environment, other groups, groups, and to themselves. Meanwhile, according to 
Geertz (1992), culture is something semiotic, namely things that are related to symbols and are known and enforced by the community concerned. Furthermore, according to Peursen (1988) culture is defined as a manifestation of the life of each person and every group of people. Based on this understanding, it shows that culture functions as a control for humans and satisfying the needs of human instincts. Culture is defined as a set of attitudes, behaviors, and symbols adopted by a group of people and passed down from generation to generation.

On the other hand, local wisdom is a characteristic of a certain area or region that has cultural values and develops in the local scope from generation to generation (Damayanti, 2009). Local wisdom can be understood as local (local) ideas that are wise, full of wisdom, of good value that are embedded and followed by community members (Damayanti, 2009). According to Keraf (in Tarakanita, 2013) that local wisdom is all forms of knowledge, belief, understanding or insight as well as customs or ethics that guide human behavior in life in ecological communities. So, local wisdom is also a view and traditional knowledge that becomes a reference in behavior and has been practiced from generation to generation to meet the needs and challenges in the life of a society. Local wisdom functions and is meaningful in society both in the preservation of natural and human resources, customs and culture, and is useful for people's daily lives.

Therefore, if the values of local wisdom are decreasing, then the values of Pancasila are also disappearing because Pancasila is adopted from traditional values, cultural values, and religious values contained in the way of life of the Indonesian people before forming a state. Tabot is a traditional ceremony of Bengkulu people, which aims to commemorate the story of heroism and the death of the grandson of the Prophet Muhammad SAW, namely Saidina Hassan bin Ali and Saidina Hussein bin Ali in the war with Ubaidillah bin Zaid's troops in the Karbala field, Iraq on 10 Muharram 61 Hijri together with 618 AD. The Tabot ceremony is held every year, from 1 Muharram to 10 Muharram to be exact. The purpose of the first Tabot tradition is to welcome the Hijri new year. The Tabot ceremony is presided over by a member of the Tabot family who masters the details of this ritual and who is considered to have the spiritual ability to carry out the ritual. Second, the Tabot is more physical. Tabot in this sense is understood as an ornament in the form of a temple or house that has one or more peaks of different sizes made from certain materials and is devoted to the Tabot ritual. The Tabot ritual is then passed down from generation to generation so that it is acculturated as the local culture of the Bengkulu people.

The Tabot ritual is not a native culture of Bengkulu Province. Rather it is a tradition brought by immigrants from Madras and Bengali (southern India) in 1685 AD. Furthermore, the ritual is carried out continuously every year on 1-10 Maharram in the Hijri year and is passed on to the descendants of these immigrants, most of whom have been assimilated with the Bengkulu people. The Tabot ritual ceremony was originally an obligation of the Tabot Harmony Family (KKT) to fulfill the will of their ancestors who had passed their culture on to their descendants. But in its development, in addition to fulfilling the will of their ancestors, the Tabot ritual is also a form of participation for the Tabot Harmony Family (KKT) in participating in the success of government programs in the fields of culture and tourism in Bengkulu Province.

Local wisdom is reflected in the long-standing habits of people's lives. The sustainability of local wisdom will be reflected in the values that apply to certain community groups. These values become the grip of certain community groups which will usually become an inseparable part of life, which can be observed through everyday attitudes and behavior, such as religious values, historical values and social values. So that the value of local wisdom at the Tabot ceremony is not lost with the times and technological advances that result in cultural shifts, efforts to preserve the Tabot culture are needed.

Based on this description, this paper aims to analyze and describe the values of local wisdom in the Tabot culture in the community, as well as efforts to preserve the values contained in the Tabot culture. 


\section{Research Methods}

This paper uses a qualitative research methodology with a phenomenological approach. According to Bogdan and Taylor (Moleong, 2004), qualitative research is a research procedure that produces descriptive data in the form of written or spoken words from people and observable behavior. Qualitative research is also called naturalistic research because the research is carried out on natural objects, namely objects that develop as they are, not manipulated by researchers and the presence of researchers does not affect these dynamics. The term naturalistic indicates that the conduct of research occurs naturally, as it is in normal situations and emphasizes natural description. Data retrieval or phenomenon networking is carried out from appropriate circumstances (natural or natural data retrieval).

This research uses Miles and Hubermen analysis technique. The selection of informants was carried out using the snowball technique. The snowball technique is interpreted as a search for data starting from the first informant who is asked for information about social interactions from aspects of cooperation, assimilation, acculturation, and accommodation. After the first informant finished and managed to find the initial data, the next step was to ask the first informant about who the next person could provide other information about the interaction.

Informant selection technique with snowball was also used as source triangulation. Source triangulation is done by comparing data obtained from various sources. The trick is to re-confirm the data obtained from the first informant to the next informant. This technique is done so that researchers can ensure which data is correct and reliable after making comparisons (triangulation of sources).

\section{Results and Discussion}

\section{History of the Tabot}

Tabot is a traditional ceremony of Bengkulu people, which aims to commemorate the story of heroism and the death of the grandson of the Prophet Muhammad SAW, namely Saidina Hassan bin Ali and Saidina Hussein bin Ali in the war against Ubaidillah bin Zaid's troops in the Karbala field, Iraq on 10 Muharram 61 Hijriah (618 AD). AD). The Tabot celebration in Bengkulu was first carried out by Sheikh Burhanuddin, better known as Imam Senggolo in 1685. Sheikh Burhanuddin (Imam Senggolo) was married to a Bengkulu woman then their children, grandchildren, and descendants were called the Tabot family. This ceremony is held from the 1st to the 10th of Muharram (based on the Islamic Hijri calendar) every year.

At first, the essence of the Tabot ceremony was to commemorate the efforts of the Shia leader and his people in collecting the remains of Husein, parading, and burying him in Padang Karbala. The term Tabot comes from the Arabic word Tabot which literally means "wooden box" or "casket". In the Qur'an the word Tabot has been known as a chest containing the Torah. The Israelites at that time believed that they would get good if this Tabot appeared and was in the hands of their leader. On the other hand, they will have disaster if the object is lost. There is no written record of when the Tabot ceremony began to be recognized in Bengkulu. However, it is strongly suspected that the tradition that departed from the morning ceremony of the Shia adherents was brought by the craftsmen who built Fort Marlborought (1718-1719) in Bengkulu.

The builders were brought in by the British from Madras and Bengal (southern India) who happened to be Shia Muslims. The workers who felt that they were similar and compatible with the Bengkulu people's way of life, led by Imam Senggolo or Sheikh Burhanuddin, decided to stay and establish a new settlement called Berkas, now known as Kelurahan Tengah Padang. The traditions brought from Madras and Bengali were passed on to their descendants who had assimilated with the original Bengkulu people and produced offspring known as the Sipai people. The mourning tradition brought from its home 
country experienced assimilation and acculturation with the local culture, and was then passed down and institutionalized into a Tabot ceremony. This Tabot ceremony is expanding from Bengkulu to Painan, Padang, Pariaman, Maninjau, Banda Aceh, Meulaboh, and Singkil. However, in its development, Tabot activities have disappeared in many places, until in the end there are only two places, namely in Bengkulu under the name Tabot, and in Pariaman, West Sumatra (entered around 1831) as Tabuik. Both are the same, but the way they are implemented is slightly different.

\section{The Form of Tabot Cultural Local Wisdom}

Tabot is one of the traditional ceremonies in the city of Bengkulu. Tabot is celebrated from the 1st to the 10th of Muharram every year with the aim of commemorating the death of the grandsons of the Prophet Muhammad, namely Hasan and Husein bin Abi Talib who were killed in Padang Karbala, Iraq by Yasid bin Muawiyyah. At the Tabot celebration, various exhibitions and competitions for fish, telongtelong, and other arts were held which were participated by art groups in Bengkulu Province. The celebration of the Tabot tradition is also at the same time an entertainment event for the people and as an annual tourism agenda. In addition to commemorating the death of the Prophet Muhammad's grandson, the purpose and objective of holding the Tabot tradition is to preserve the Bengkulu people's culture, as a form of respect for the character of Husein bin Abi Talib.

The celebration of the Tabot tradition in Bengkulu which is routinely held every year is a cultural attraction wrapped in religion that is very popular with tourists, both domestic and foreign. When the ceremony is held, it is certain that hundreds or even thousands of people will flock along the main streets and squares of Bengkulu city to witness the various stages of the interesting and sacred processions that are held in this cultural tourism event. Apart from holding ritual ceremonies, it is usually also enlivened with art performances, folk markets, craft exhibitions, and various other art events. The forms of local wisdom of Tabot culture can be described as follows:

\section{Musical Instruments Used in the Tabot Ceremony}

Dol is made of wood with a hole in the middle and then covered with cowhide. Dol is shaped like a drum. The diameter is about $70-125 \mathrm{~cm}$, and the bat is $5 \mathrm{~cm}$ in diameter and $30 \mathrm{~cm}$ in length. The way to play $D o l$ is by beating it. While Tesa is shaped like a tambourine, made of copper, iron plate or aluminum, and can also be from a cauldron whose surface is covered with dried goat skin. The musical instruments used are usually to accompany the folk songs that are sung at the Tabot ceremony.

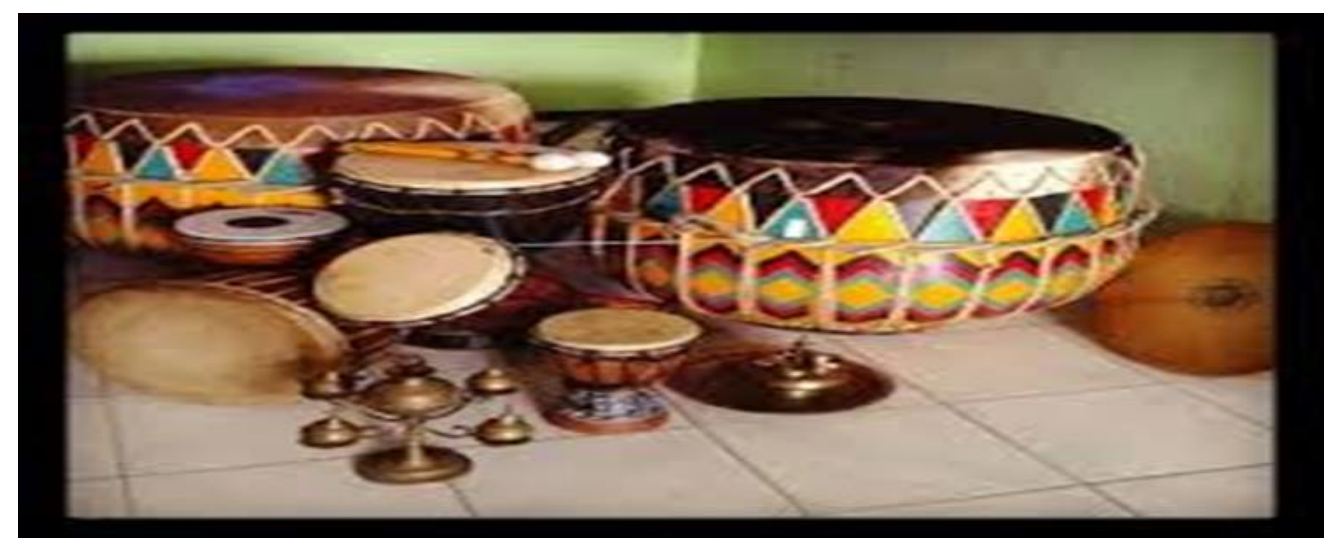

Figure 1. Dol and Tesa

Source: Researcher Documentation of 2020 


\section{Traditional Clothes}

Bengkulu men's traditional clothes consist of a suit, trousers, footwear and also accompanied by a headgear. While for Bengkulu women's traditional clothes, in general they have similarities with Malay traditional clothes. The traditional clothes are in the form of long-sleeved brackets made of velvet. This bracket is also decorated with gold embroidered motifs and is round like a coin plate. The most commonly used colors are dark red, mauve blue and also black. For their subordinates, the Bengkulu women used songket cloth made of silk decorated with gold motifs.

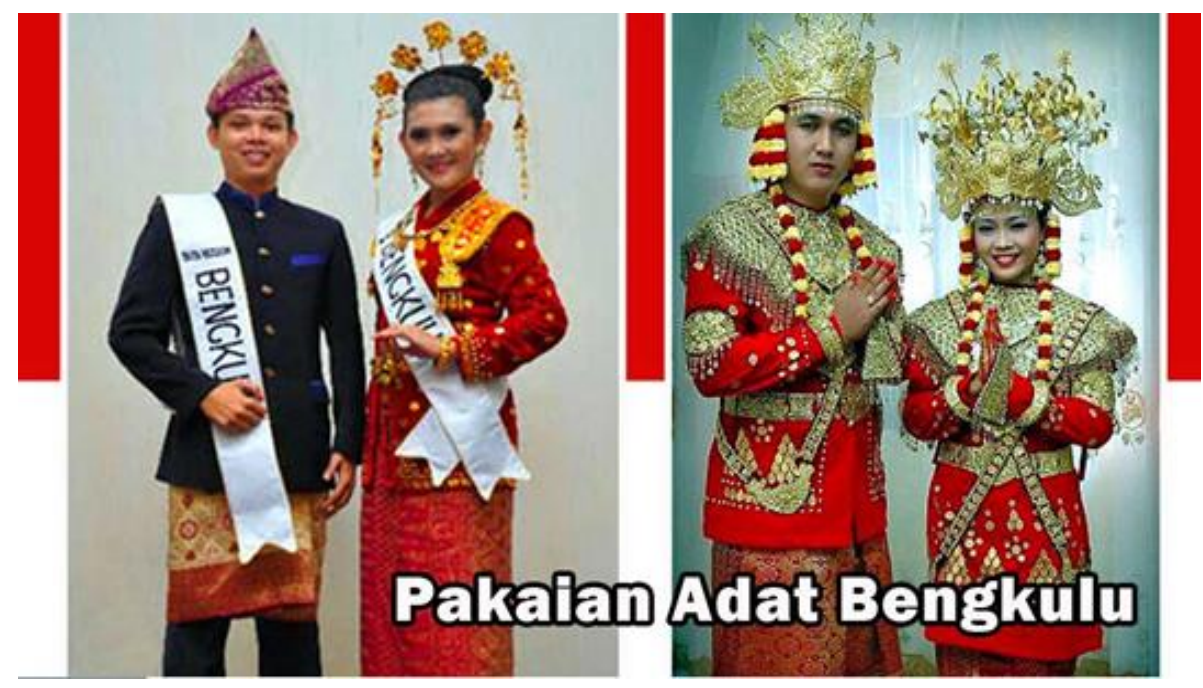

Figure 2. Traditional Clothing Used in the Tabot Ceremony Source: Researcher Documentation of 2019

\section{Local Language}

The language families used in Bengkulu Province include: Ra-Hyang or Re-Hyang (Rejang), Enggano (Women's Island), Lampung, Ippoh Malay (Muko-muko, Lubuk Pinang, Pillow, Lima Koto, Ketahun, Pasar). Bengkulu, etc.), Lembak Malay (Tanjung Agung, Dusun Besar, Pada Dewa, etc.) and Bengkulu City Malay. The Tabot ceremony generally uses the Bengkulu City Malay language. The various regional languages of the people in Bengkulu province are as follows:

- The Rejang ethnic community uses the rejang language in their daily life. Some call the rejang language the name Rejang-Lebong, Jang, Djang Bele Tebo. This language has its own accent called kangongo. There are several different dialects in use, namely kepahiang, lebong, coastal, selupuh, musi, and rawas.

- The Pasemah ethnic group living in Bengkulu uses the Pasemah language. Pasemah language is still the Malay language family.

- The Mukomuko ethnic group living in Mukomuko district uses the Minangkabau language which has been mixed with the Rejang language.

- Malay language with Bengkulu dialect is used by ethnic Malay people who live in Bengkulu, the coast of North Bengkulu, and South Bengkulu.

- The Kaur people who live in the Kaur district use the Mulak language in their daily interactions.

- The Serawai people in South Bengkulu and Seluma districts use the Serawai language. Serawai language has several dialects, namely Serawai and Manna dialects. 
- The Lembak people who live in Rejang Lebong, North Bengkulu, and South Bengkulu districts use the Mulang language.

In addition to these regional languages, there are still many regional languages with different dialects used by the tribes in Bengkulu, such as the Krui language and the Pekal language. Although there are many regional languages found in Bengkulu province, for communication between tribes, they use Indonesian.

\section{Food and Drink}

The food and drink that is often found at the Tabot Ceremony is Gelamai, which is a typical Bengkulu dodol. Then Belly Punai, Anggut Coffee, Pais Fish (Bengkulu typical Pepes), Lemang, Snail Cake, Lontong Ajo, Lumrub, etc.

\section{Tabot Culture Local Wisdom Values}

\section{Tabot Cultural Religious Values}

Every action in the Tabot ceremony always begins with the reading of the Basmalah and prayers. These prayers include prayers for the grave, prayers for safety and forgiveness for the souls of Muslims in the world, reading tasbih, sholawat ulul 'azmi, sholawat wasilah, etc. Apart from praying, this procession also holds a gathering (consensus) to prepare for the implementation of the Tabot celebration which usually lasts for 13 days for the families of the Tabot heirs, while the general public only knows about the Tabot ritual cultural procession until the 10th of Muharram as the climax procession.

\section{Tabot's Socio-Cultural Values}

Social values are a set of rules or a concept related to the order of social life about something that is considered good or bad, appropriate or inappropriate, beautiful or not beautiful, and right or wrong. The social values referred to in this context are the behavior of the people who used to feel warm, full of kinship, mutual respect, especially to the elders, caring for each other, helping each other and helping each other among the community. Each series in the Tabot ceremony contains social values in the form of caring for each other, helping each other among the community in the smooth running of the Tabot event.

\section{Tabot Culture Moral Values}

Moral values in the Tabot culture are seen during the Meradai procession (raising funds). This ceremony is held on the 6th of Muharram. Fundraising is done to meet the cost of making Tabot which will be at the festival. The collected funds are handed over to the respective Head of Tabot. Another Tabot procession, Arak Penja (parading the fingers) also contains positive values. Penja parade is held on the 8th of Muharram. Parading the fingers is an activity carried out by all ceremony participants. The Tabot and its fingers are paraded by marching according to predetermined paths. Through the procession, social values will be instilled, such as forgiveness, self-sacrifice, and not holding grudges.

Another Tabot procession, namely the turban wine, was held on the 9th of Muharram. The turban being paraded symbolizes the turban worn by Husain. The turban symbolizes greatness in the struggle to defend the truth. The turban wine contains the values of togetherness, sacrifice and struggle. The next Tabot ritual is Gam (quiet period). At this time all activities related to the Tabot ceremony may not be carried out. The quiet period is intended as a period of mourning in commemoration of the death of Husayn. The mourning period is carried out as an expression of concern or sadness over the death of a fellow Muslim brother. Next is the gedang arak ritual which is a ritual of releasing Tabot side by side from the gerga 
(respective group). After being released, Tabot was paraded from his base by following a predetermined path. The procession will form a gedang (large parade) procession to the Merdeka square. This procession became crowded because the entire Tabot group, followers of the Tabot event, entertainment groups, and people who wanted to see the gendang (big parade) came together. The parade will end after all of the Tabots and the group of entertainers gather at Merdeka square.

The Tabots that had gathered in rows were lined up. Tabots that are lined up are called side-by-side Tabots. The drum procession or a large parade and Tabot side by side is an event to gather strength in order to fight the enemy. As it is known that on the 9th of Muharram, the few remaining followers of Husayn received instructions and directions in dealing with the enemy. When the Tabots are juxtaposed, the public is entertained by music and $\mathrm{Dol}$ (drums) performed by their respective Tabot groups. At the time of the Tabot incident, the beauty of the Tabot was seen accompanied by the sounds of Dol (drums). After the complete Tabot participants were matched, the Tabot group returned to their respective places while waiting for the time for the Tabot to be redeemed on the 10th of Muharram. In the Tabot procession, the ransom contains positive values. The whole series of this Tabot ritual ends at the ransom Tabot. By throwing away the Tabot, it means that the entire series of activities of the Tabot ceremony have been completed.

\section{Efforts to Preserve the Tabot Culture}

The Tabot tradition which is routinely held every year has become one of the cultural attractions in Bengkulu Province. During the Tabot ceremony, there is a ritual which is a tradition carried out by the Bengkulu Tabot Harmony Family (KKT). The Tabot tradition has been passed down from generation to generation so that it is acculturated as the local culture of the Bengkulu people. One of the objectives of the Bengkulu City Government is to form a policy for the Tabot festival, namely as a form of government effort in preserving the culture of Bengkulu City.

On the other hand, there are supporting prayers and inhibiting prayers in the effort to preserve the Tabot culture which can be described as follows:

1. Supporting Factors

a. Support from the descendants of the Tabot family.

b. Support from the community around the house

c. Support from art studios in Bengkulu.

2. Obstacle Factors

a. Local government support

b. The negative perception of the non-Tabot community towards the Tabot culture.

c. Conflicts among members of the sacred Tabot family.

d. The values contained in each Tabot ritual are less socialized.

e. Many members of the Tabot family do not fully understand the values contained in each Tabot ritual that is carried out.

The emergence of the classification of inhibiting factors and supporting factors in cultural preservation proves that in a dynamic community or society tends to experience socio-cultural changes, where changes in socio-cultural life occur because the nature and nature of humans is dynamic and always wants to make changes.

\section{Conclusion}

The forms of local wisdom of the Tabot culture consist of local wisdom in the form of musical instruments used in the Tabot ceremony, traditional clothes, and local languages used, as well as food and 
drinks. Meanwhile, local wisdom is intangible in the form of values contained in the Tabot ceremony, including a congratulations prayer which means to always remember Allah SWT, asking for the safety of the hereafter and safety during the implementation of the Tabot ritual. Then Taking Land contains the value that all humans are from the ground and will return to the ground, Sitting Penja contains the value of praying to Allah SWT, Menjara contains the value of friendship and jihad to keep upholding the sentence of monotheism, Meradai contains the value of empathy from the community, Arak Penja and Turban wine contains the value of respect for Al-Husein who died in Padang Karbala, Gham contains the value of sad day for the death of al-Husein in Padang Karbela, Tabot Puncak and Arak Gedang contain the value of the glory of Islam, Tabot ransom contains the meaning of visiting the grave and throwing away traits human evil and Penja Wash contains the meaning of self-purification.

Efforts to preserve Tabot culture are influenced by several inhibiting factors in the form of minimal local government support, negative perceptions of non-Tabot communities towards Tabot culture, conflicts between Tabot family members and the values contained in each Tabot ritual are less socialized. As for the supporting factors in general, it can be said that there is social support from several parties, namely support from the descendants of the Tabot family, support from the community and support from art studios in Bengkulu.

\section{References}

Boas, F. (1938). The Mind of Primitive Man. New York: Columbia University

Damayanti, W. (2009). STRUKTUR DAN NILAI BUDAYA DALAM UKURAN CERITA PENDEK ROBOHNYA SURAU KAMI KARYA AA NAUIS (Doctoral dissertation, Universitas Pendidikan Indonesia).

Geertz, C. (1992). Kebudayaan dan Agama, terj. Francisco Budiman Hardiman. Yogyakarta: Kanisius.

Gumay, S. (2011). Tradisi Tabot Sebagai Medium Pemersatu Masyarakat Kelurahan Berkas Kecamatan Kota Bengkulu. Akses, 8(1), 82-90.

Moleong, L. J., \& Edisi, P. R. R. B. (2004). Metodelogi penelitian. Bandung: Penerbit Remaja Rosdakarya.

Peursen, C. V. (1988). Strategi Kebudayaan Edisi Kedua. V. Peursen, Strategi Kebudayaan Edisi Kedua. Yogyakarta: Gunung Mulia.

Tarakanita, I., \& Cahyono, M. Y. M. (2015). Komitmen identitas etnik dalam kaitannya dengan eksistensi budaya lokal. Zenit, 2(2).

\section{Copyrights}

Copyright for this article is retained by the author(s), with first publication rights granted to the journal.

This is an open-access article distributed under the terms and conditions of the Creative Commons Attribution license (http://creativecommons.org/licenses/by/4.0/). 